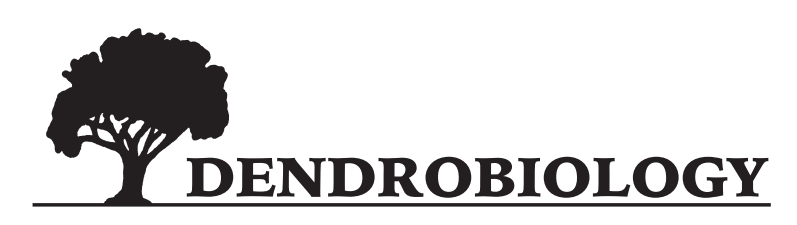

2016, vol. 75, 141-155

http://dx.doi.org/10.12657/denbio.075.014

\author{
Jiři Velebil, Bohumil Trávniček, Michal Sochor, Petr Havliček
}

\title{
Five new bramble species (Rubus, Rosaceae) in the flora of the Czech Republic
}

\begin{abstract}
This paper presents the results of extensive field research on the occurrence of Rubus L. species in the Czech Republic, especially in the frontier areas near the German border. In this area, Rubus adornatus, $R$. fasciculatiformis and R. perlongus were newly discovered. The other species, R. ambulans and R. stohrii, were discovered in the eastern and northern parts of Bohemia. A description, an illustration, photos and a list of localities are provided for each species. Taxonomy and nomenclature, ecology, distribution and etymology are discussed. The ploidy level of the mentioned species is presented here for the first time. All of these species are new for the flora of the Czech Republic.
\end{abstract}

Key words: description, ecology, geographical distribution.

Addresses: J. Velebil, Silva Tarouca Research Institute for Landscape and Ornamental Gardening, Publ. Res. Inst., Květnové náměstí 391, 25243 Průhonice, Czech Republic, e-mail: velebil@vukoz.cz B. Trávníček, Department of Botany, Faculty of Science, Palacký University, Šlechtitelů 27, 78371 Olomouc, Czech Republic

M. Sochor, Department of Botany, Faculty of Science, Palacký University, Šlechtitelů 27, 78371 Olomouc, Czech Republic; Centre of the Region Haná for Biotechnological and Agricultural Research, Department of Genetic Resources for Vegetables, Medicinal and Special Plants, Crop Research Institute, Šlechtitelů 29, 78371 Olomouc, Czech Republic

P. Havlíček, Department of Botany, Faculty of Science, Charles University, Benátská 2, 128 01, Praha 2,

Czech Republic

\section{Introduction}

The monographic treatment of brambles in the Flora of the Czech Republic (Holub, 1995) was published twenty years ago. In consequence of extensive field study and modern biosystematic methods used in plant taxonomy, many new species have been recognized (e.g., Trávníček \& Zázvorka, 2005; Lepší \& Lepší, 2006, 2009). Currently, several other undescribed taxa are being intensively studied. Simultaneously, a new publication that will be a vignette of recent scientific field discoveries of Czech brambles is being prepared. More detailed investigation, espe- cially in omitted areas, was performed in the course of its preparation. The partial result of this research is the discovery of five Rubus species new in the flora of the Czech Republic, which we introduce below. It cannot be ruled out that other neighbouring species will be found in the frontier areas in the future.

\section{Methods}

Recently, a long-term extensive field study of bramble taxa in the Czech Republic was focused on the frontier zone, where the occurrence of some neighbouring species was supposed. Some previous- 
ly omitted areas in the interior of Bohemia were also examined. The overall geographic distribution of treated species was compared especially with Kurtto et al., 2010 and Bettinger et al., 2013. Authors of plant names are abbreviated according to Brummitt \& Powell (1992) or IPNI (2015). The localities of the species were classified according to the regional-phytogeographical division (Skalický, 1988) and were arranged according to the Central European grid mapping using the method of Ehrendorfer \& Hamann (1965). Altitudes and positions in WGS 1984 were determined using a Garmin GPSMAP 60CSx instrument together with MapSource software (with TOPO Czech PRO 2010 maps). For the abbreviations of public herbaria, see Holmgren et al. (1990). The herbarium of the Mining Museum Príbram is abbreviated as HOMP (see Index Herbariorum, 2015). The herbarium of the Silva Tarouca Research Institute for Landscape and Ornamental Gardening, Publ. Res. Inst. is abbreviated as RILOG. Authors' or collectors' names are abbreviated as: BT $=$ Bohumil Trávníček, $\mathrm{JH}=$ Jiří Hadinec, JV = Jiř́ Velebil, $\mathrm{PH}=$ Petr Havlíček, RH = Rudolf Hlaváček, VZ = Vojtěch Žíla.

The ploidy level of the studied accessions was assessed based on DNA content, as determined by the FCM of fresh leaves using an BD Accuri ${ }^{\mathrm{TM}} \mathrm{C} 6$ instrument. As an internal standard, Lycopersicon esculentum 'Stupické polní rané' $(2 \mathrm{C}=1.96 \mathrm{pg}$; Doležel et al., 2007) was used. The leaf tissue of the sample and the standard were chopped together with razor blade in 0.5 mL LB01 buffer (Doležel et al., 1989; 15 mM Tris, $2 \mathrm{mM}$ EDTA, $0.5 \mathrm{mM}$ spermine tetrahydrochloride, $80 \mathrm{mM} \mathrm{KCl}, 20 \mathrm{mM} \mathrm{NaCl}, 0.1 \%$ Tritone X-100, 30 $\mathrm{g} / \mathrm{L}$ PVP40, $550 \mu \mathrm{L} / \mathrm{L} 2$-mercaptoethanol, $\mathrm{pH}=8.0$ ). The suspension was filtered through $42 \mu \mathrm{m}$ nylon mesh, and $20 \mu \mathrm{L}$ of propidium iodide was added. At least 3,000 particles were measured, including only the peaks of the sample and the standard. BD Accuri C6 Software was used to calculate the peak position and the coefficient of variation $(\mathrm{CV})$. Only measurements with CV $<4.3 \%$ were accepted. The ploidy level of each sample was calculated from the ratio of the relative fluorescence intensity for the sample/ standard; this ratio was compared to that obtained for cultivated accessions of different species with known chromosome counts.

Detail photographs of each species are added in the electronic appendix.

\section{Results and discussion}

\section{Rubus adornatus P. J. Müll. ex Wirtg., Flora 42: 234, 1859.}

Description: Shrub, usually up to $80 \mathrm{~cm}$ tall. First-year stems mainly arching, rooting at apex, angular with \pm flat sides, mostly $5.5-6(-8) \mathrm{mm}$ in diameter, matt green, at sunny sites suffused distinctively vinaceous, with 50-200 simple and bundled hairs $(0.8-1.5 \mathrm{~mm}$ long) per $1 \mathrm{~cm}$ of stem side, reaching up to prickles; stalked glands usually 10-30 per $1 \mathrm{~cm}$ of stem side, up to $1 \mathrm{~mm}$ long. Prickles (10-) 15-20(-25) per $5 \mathrm{~cm}$ length of stem, mildly different, straight to slightly curved, somewhat declining, (4-)6-8 mm long, with a base (3-)5-7 mm broad, suffused red, with a yellowish tip.

Leaves on first-year stems palmate or nearly pedate, (3-)5-foliolate, usually \pm three-dimensional (with leaflets often slightly concave, with raised margins, somewhat rugose), deep to dark green above (covered with 20-40 subadpressed hairs per $1 \mathrm{~cm}^{2}$ ), light green or yellowish-green beneath (densely patent-hairy to the touch, without stellate hairs). Leaflets \pm contiguous, the terminal with relatively short petiolule (petiolule $20-35 \%$ as long as its lamina), obovate to slightly rhombic, rounded or slightly cordate at base, \pm abruptly narrowing into a $13-22 \mathrm{~mm}$ long apex; leaflet margins mildly crispate, indentation periodic, with incisions $2-3 \mathrm{~mm}$ deep. Petiolules of the basal leaflets $2-5 \mathrm{~mm}$ long. Petioles usually 6-8 cm long, \pm as long as the basal leaflets or longer, densely pubescent with stalked glands and 10-20 slender, strongly declining and distinctly curved prickles; stipules filiform to narrowly lanceolate, ca 1 $\mathrm{mm}$ wide, hairy and with sparse stalked glands.

Inflorescence paniculate, pyramidal, with erecto-patent to (in upper part of inflorescence) \pm patent branches, distal 5-9 cm part leafless. Inflorescence leaves predominantly ternate (the uppermost 1-2 leaves simple), yellowish-green beneath, without stellate hairs. Inflorescence axis \pm flexuous, densely hairy, with numerous stalked glands and 8-20 prickles per $5 \mathrm{~cm}$ axis length; prickles slender, slightly curved, declining, 4-6 mm long. Pedicels densely pubescent, with numerous stalked glands ( \pm as long as hairs) and 8-20 acicular, mostly straight and only slightly declining, 1-3 mm long prickles.

Sepals 8-11 mm long (inclusive of the conspicuous reddish linear appendix), reflexed after anthesis, greyish-green, with a white felted margin, and with scattered stalked glands and short reddish prickles. Petals pale pink, 8-11 mm long, not touching each other. Stamens longer than styles, filaments rose, anthers glabrous. Carpels glabrous, styles with reddish base. Receptacle sparsely hairy. Fruit semiglobose to globose. Flowering VII-VIII.

Illustrations: Fig. 1., Sudre (1912: 173, fig. 168, excl. infraspecific taxa); Matzke-Hajek (1993: 121, fig. 13), Haeupler \& Muer (2000, 2007: 257, fig. 1338).

Chromosome number has not been reported (see also Kurtto et al., 2010: 146); DNA ploidy level (stated in this study on specimen no. R309/13 (OL) from 


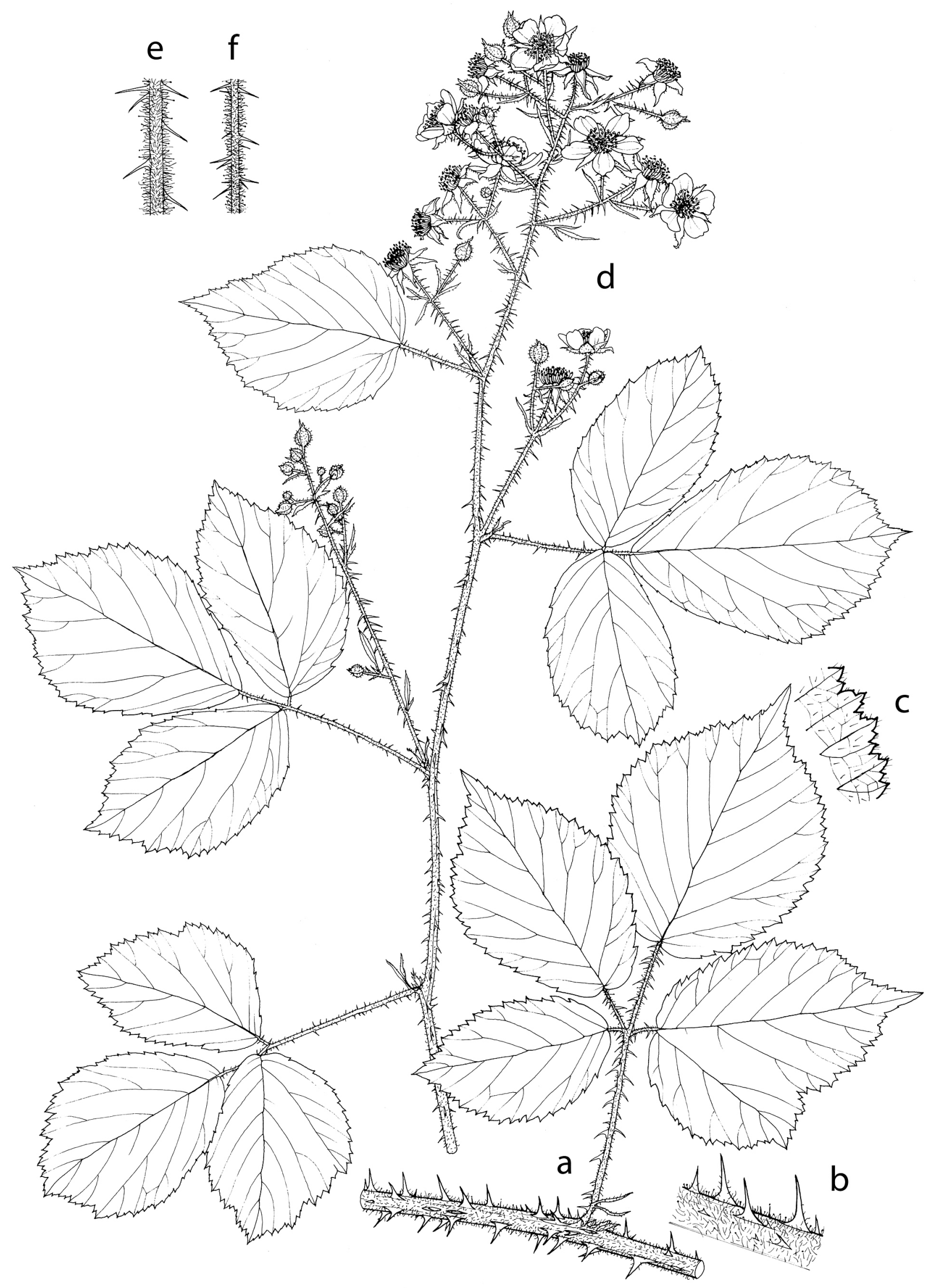

Fig. 1. Rubus adornatus: $\mathrm{a}$ - leaf with part of first-year stem; $\mathrm{b}$ - detail of first-year stem with prickles; $\mathrm{c}$ - margin of terminal leaflet showing indentations; $\mathrm{d}$ - inflorescence; $\mathrm{e}$ - detail of inflorescence axis; $\mathrm{f}$ - detail of peduncle. Drawing by A. Skoumalová 
the Czech locality mentioned below): $2 \mathrm{n}=4 \mathrm{x}$ (corresponding to $2 \mathrm{n}=28$ ).

Taxonomy and nomenclature: Rubus adornatus is a member of series Vestiti (Focke) Focke of the subgenus Rubus section Rubus and subsection Hiemales E. H. L. Krause. In the frame of the Czech bramble flora, it resembles no members of the series. Rubus adornatus can be distinguished from other Czech Rubus species by the following features combination: stems with 15-20, mildly different, straight to slightly curved, somewhat declining prickles per $5 \mathrm{~cm}$ length of stem; leaves on the first-year stems 3-5-foliate, somewhat rugose, densely patent-hairy to the touch, without stellate hairs, indentation periodic, with incisions $2-3 \mathrm{~mm}$ deep; petals pale pink. It can resemble some members of the Rubus series Hystrix Focke, but species of this group have strongly different prickles on the first-year stems that are mostly less hairy and covered by more numerous stalked glands.

Type material: lectotype: An Hecken bei Coblenz, im Lahntal und durch die Eifel sehr häufig, 20.7.1858, Ph. Wirtgen, herbarium LAU, designed by Weber (1995a).

Czech name (proposed here): "ostružiník ozdobný".

Discovered occurrence in the Czech Republic (documented by herbarium specimens): Western Bohemia, 22. Halštrovská vrchovina: Hranice village (Cheb district), approximately 2,7 km WNW from the church in the village and approximately $500 \mathrm{~m}$ NW from the former military base, a NE margin of spruce growth approximately $200 \mathrm{~m} \mathrm{NW}$ from the monument of victims of the world war, $600 \mathrm{~m}$ a.s.l., 5638d: 50¹8'26”N, 1208'24'” (leg. JV, 31 August 2013, RILOG 130814); the same locality (leg. BT, 6 September 2013, R309/13, OL); the same locality and date (leg. $\mathrm{JH}$ and $\mathrm{VZ}$, herb. JH and VZ); the same locality (leg. JV, 5 July 2014, RILOG 140730).

Ecology and geographical distribution: Rubus adornatus is a mostly nemophilous species. It occupies localities predominantly poor in nutrients and acid soils (usually clay soils) in hilly areas with a tendency to ascend to submontane locations.

This species occurs in western Germany (Rhineland-Palatinate, North Rhine-Westphalian, Hesse, see Bettinger et al., 2013: 649), Belgium, Netherlands and Luxembourg (see Helminger, 2009; Kurtto et al., 2010). Additionally, one locality in the Czech Republic separated from a margin of its continuous distribution area by a distance of approximately $150-200 \mathrm{~km}$ is known. Rubus adornatus presents here considerably isolated easternmost particular area of its distributional range. The Czech population consists of a few scattered polycorms in the area of approximately 3 ha in one isolated, mainly spruce plantation.

\section{Rubus ambulans Matzk., Ber. Bayer. Bot. Ges. 73-74: 28, 2004.}

Synonymy: Rubus gremlii auct., non Focke

Description: Shrub, usually up to $100 \mathrm{~cm}$ tall. First-year stems arching, sometimes climbing, rooting at apex, angular, with flat or slightly furrowed sides, usually $5-8 \mathrm{~mm}$ in diameter, matt green, suffused vinaceous on the side exposed to the sun, with 10-30 simple and tufted hairs (up to $1 \mathrm{~mm}$ long) per $1 \mathrm{~cm}$ of stem side, without stalked glands (with sessile glands only). Prickles almost uniform, 5-12 per $5 \mathrm{~cm}$ length of stem, slightly to distinctly curved, somewhat declining, 4-6(-7) $\mathrm{mm}$ long, with a base 4-7 mm broad, yellowish-green or reddish to vinaceous with yellowish tip.

Leaves on first-year stems palmate or subpedate, 5-foliolate, usually three-dimensional (not flat), somewhat leathery and glossy, usually glabrous above, green to greyish-felted (on sunny sites) beneath, thin hairy, with stellate adpressed hairs and scattered short simple hairs, only slightly hairy to the touch. Terminal leaflet with rather long petiolule (petiolule $30-40(-44) \%$ as long as its lamina), elliptical to ovate, usually shallowly cordate at base, gradually (to subabruptly) narrowing into a long (20-30 $\mathrm{mm}$ ) apex; leaflet margins \pm flat, slightly periodically to almost evenly dentate, teeth broad, apiculate, incisions 1.5-2.5 mm deep. Petiolules of the basal leaflets $4-8(-10) \mathrm{mm}$ long. Petioles usually $6-8 \mathrm{~cm}$ long, \pm as long as the basal leaflets, sparsely hairy, usually without stalked glands, with (10-)12-18 strongly declining and distinctly curved prickles $2.5-4 \mathrm{~mm}$ long; stipules filiform-linear, ca $1 \mathrm{~mm}$ wide, sparsely hairy, sometimes with single short stalked glands.

Inflorescence paniculate, as a rule not too rich, narrowly pyramidal, with erecto-patent to almost patent (in upper part of inflorescence) branches, distal leafless part usually 4-8 cm long. Inflorescence leaves predominantly ternate (the uppermost $1-2$ often simple, the lowermost sometimes 4-5-foliolate), leaflets with similar dentation and similarly hairy as on the first-year stems. Inflorescence axis flexuous, with subadpressed tufted hairs (especially in upper part) and almost patent longer hairs, without or rarely with 1-2 stalked glands per $5 \mathrm{~cm}$ of axis length, with 3-8 prickles per this length; prickles from rather broad base suddenly narrowed, declining and usually curved, 3-4 mm long. Pedicels densely hairy, with rather intertwined stellate and tufted hairs, usually without stalked glands (but these glands sometimes present on the adjacent bracts), with 4-12 slender, mostly only slightly declining and curved prickles 1-2 mm long.

Sepals 5-8 $\mathrm{mm}$ long, reflexed after anthesis, greygreen felted, also with longer patent hairs, usually unarmed. Petals white to (rarely) pinkish, elliptic 


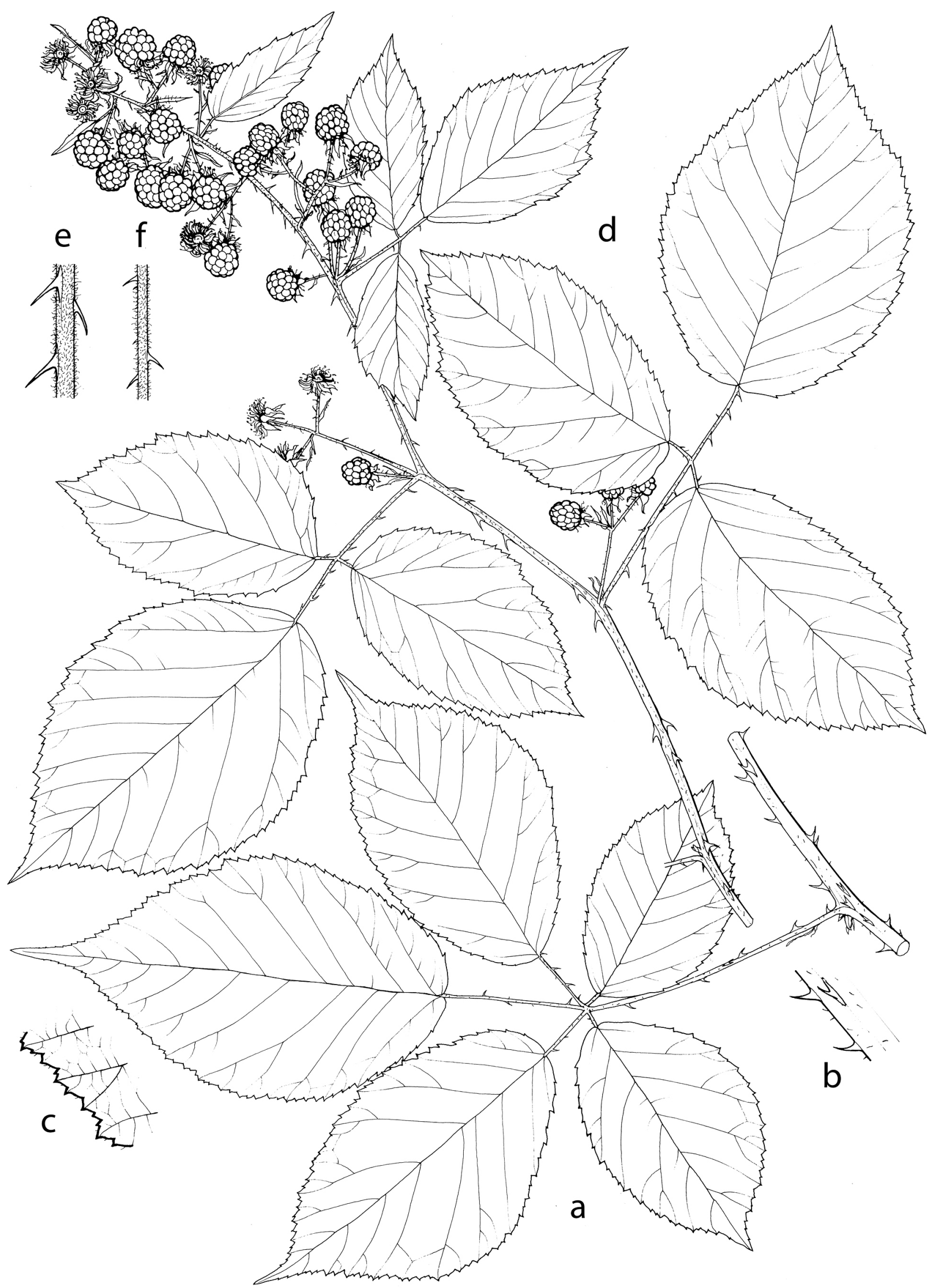

Fig. 2. Rubus ambulans: $\mathrm{a}$ - leaf with part of first-year stem; $\mathrm{b}$ - detail of first-year stem with prickles; $\mathrm{c}$ - margin of terminal leaflet showing indentations; $\mathrm{d}$ - infructescence; $\mathrm{e}$ - detail of inflorescence axis; $\mathrm{f}$ - detail of peduncle. Drawing by A. Skoumalová 
to obovate, ca $10 \mathrm{~mm}$ long and 5-6 $\mathrm{mm}$ wide, not touching each other. Stamens longer than styles, filaments whitish, anthers glabrous. Carpels sparsely hairy on the top, styles greenish. Receptacle sparsely hairy. Fruit usually globose. Flowering (VI-) VII-VIII.

Illustrations: Fig. 2, Haeupler \& Muer (2000, 2007: 251, fig. 1301, as R. gremlii); Matzke-Hajek (2004b: 30, fig. 4 (holotype)).

Chromosome number has not been reported; DNA ploidy level (stated in this study on the specimens no. R292/13 and no. R296/13 (both OL) from the localities a. and g. mentioned below): $2 \mathrm{n}=4 \mathrm{x}$.

Taxonomy and nomenclature: Rubus ambulans is a member of series Silvatici (P. J. Müll.) Focke of the subgenus Rubus section Rubus and subsection Hiemales.

Rubus ambulans is a recently recognized bramble species, separated from similar species of $R$. gremlii Focke by Matzke-Hayek (2004b). Although H. E. Weber synonymizes (Kurtto et al., 2010: 120) this species with $R$. gremlii, we think that it is a separate species because we have never observed the important taxonomic characteristics of $R$. gremlii s. str. in the Czech populations. On the other hand, the Czech plants have characteristics that are typical for $R$. ambulans. We identified only one difference against the original description of $R$. ambulans: Czech specimens have glabrous upper sides of the leaves on first-year stems (not with 5-10 hairs on $1 \mathrm{~cm}^{2}$ of the surface as mentioned in the original description). However, we found identical "glabrous" specimens also on a Bavarian locality of $R$. ambulans, which we visited for comparison. The Czech plants are completely identical with the Bavarian specimens in all morphological characteristics. $R$. gremlii s. str. is an extremely rare (probably one locality only in Baden-Württemberg) taxon in Germany; it has more localities in Switzerland. For details of its distribution and comparison of $R$. gremlii and R. ambulans, see Matzke-Hajek (2004b: $23,29,33)$.

In the frame of the bramble flora of the Czech Republic, where $R$. gremlii is absent, $R$. ambulans is most similar to $R$. macrophyllus Weihe (it is also member of series Sylvatici). However, R. macrophyllus has only slightly curved prickles on the first-year stems, often convex leaflets, terminal leaflets with a more distinctly cordate base and often with a hint of parallel sides and with somewhat shorter apex. Moreover, it has usually more noticeable principal teeth of the leaf margin that are sometimes little retrorse and leaves that are not as felted beneath (by stellate hairs) as $R$. ambulans has in sunny sites.

Type material: holotype: Deutschland, Rheinland-Pfalz, Kreis Bitburg-Prüm, $1 \mathrm{~km}$ südwestlich Scharfbillig, Waldrand bei P. 366,8 (TK 6005.32), leg. G. Matzke-Hajek 22.7.1998, herbarium B, 980722.7; isotypes in FR, M, LUX (see Matzke-Hajek 2004b). jící".

Czech name (proposed here): "ostružiník putuDisce

Discovered occurrence in the Czech Republic (documented by herbarium specimens): (a.) Eastern Bohemia, 65. Kutnohorská pahorkatina: Kraborovice village (Havlíčkův Brod district), margin of the way in the wood at the road near the Točice settlement, ca $0.6 \mathrm{~km} \mathrm{NW(-WWN)}$ from the main crossroad in the village, ca $380 \mathrm{~m}$ a.s.l., $6159 \mathrm{c}: 49^{\circ} 48^{\prime} 11^{\prime \prime} \mathrm{N}$, $15^{\circ} 33^{\prime} 40^{\prime \prime} \mathrm{E}$ (leg. PH, 28 October 2001, herb. PH); the same locality (leg. BT, 5 September 2013, R292/13, OL); (b.) Eastern Bohemia, 65. Kutnohorská pahorkatina: Vrtěšice village (Havličkův Brod district), forest ca $0.5 \mathrm{~km}$ SE from the village, 6159c: $49^{\circ} 48^{\prime} 27^{\prime \prime} \mathrm{N}$, 1530'17”'E (leg. PH, 28 October 2001, herb. PH); (c.) Eastern Bohemia, 66. Hornosázavská pahorkatina: Nasavrky village (Havlíčkův Brod district), forest margin at the road towards Zhoř settlement, ca $0.7 \mathrm{~km}$ SE from the village, ca $410 \mathrm{~m}$ a.s.l., 6259a: $49^{\circ} 47^{\prime} 45^{\prime \prime} \mathrm{N}, 15^{\circ} 30^{\prime} 04^{\prime \prime} \mathrm{E}$ (leg. PH, 28 October 2001, herb. PH); the same locality (leg. BT, 5 September 2013, R295/13, OL); (d.) Eastern Bohemia, 66. Hornosázavská pahorkatina: Hostovlice village (Havlíčkův Brod district), forest ca $0.7 \mathrm{~km}$ WWS from the

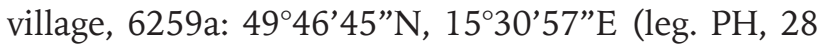
October 2001, herb. PH); (e.) Eastern Bohemia, 66. Hornosázavská pahorkatina: Kobylí Hlava settlement (Havlíčkův Brod district), forest ca $1 \mathrm{~km} \mathrm{NNE} \mathrm{from} \mathrm{the}$ settlement, 6258b: 4947’37”N, 1527'33" E (leg. PH, 13 September 2001, herb. PH); (f.) Eastern Bohemia, 66. Hornosázavská pahorkatina: Druhanov village (Havlíčkův Brod district), under a powerline at the forest ca $1 \mathrm{~km} \mathrm{~S}$ from the village, 6358a: $49^{\circ} 41^{\prime} 25^{\prime \prime} \mathrm{N}$, $15^{\circ} 24^{\prime} 32^{\prime \prime E}$ (leg. PH, 13 September 2001, herb. PH); (g.) Central Bohemia, 66. Hornosázavská pahorkatina: Červené Janovice village (Kutná Hora district), shrubs at the road towards Zhoř village, near a small pond on the southeastern village margin, ca $460 \mathrm{~m}$

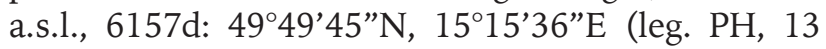
September 2001, herb. PH); the same locality (leg. BT, 5 September 2013, R296/13, OL).

Ecology and geographical distribution: The species grows on the margins of mixed forests, their clearings, in bushes along roads and forest ways, on neutral or weakly acidic, usually mesic soils.

Rubus ambulans is a so-called widespread (see Weber, 1999) bramble species. Matzke-Hajek (2004b) reported it from quite a large distribution area. Its general distribution covers many regions of Germany (Thuringia, Hesse, Saarland, Rhineland-Palatinate, Baden-Württemberg and Bavaria) from which it extends to France (rare in Lorraine) and Luxembourg. For the distribution area in the Germany, see Bettinger et al. (2013: 649). The newly discovered area of the species in the Czech Republic is isolated and extends its known distribution quite significantly to the east. 


\section{Rubus fasciculatiformis H. E. Weber, Ber. Bayer. Bot. Ges. 50: 10, 1979.}

Description: Shrub, usually up to $80 \mathrm{~cm}$ tall. First-year stems mainly low-arching, rooting at apex, bluntly angled with \pm flat sides, mostly (4-)5-6 mm in diameter, matt greyish-green, sunny sites suffused vinaceous, with 0-3(-10) mostly bundled hairs per 1 $\mathrm{cm}$ of stem side, up to $1 \mathrm{~mm}$ long, predominantly on the prickles bases; stalked glands usually $0-15$ per 1 $\mathrm{cm}$ of stem side, up to $0.4 \mathrm{~mm}$ long. Prickles $12-20$ per $5 \mathrm{~cm}$ length of stem, mildly different, straight to slightly curved, somewhat declining, 3.5-5 mm long, with a base $3-4.5 \mathrm{~mm}$ broad, yellowish-green.

Leaves on first-year stems palmate or nearly pedate, 3-5-foliolate, \pm flat (with leaflets rugose and somewhat convex), deep greyish-green above, covered with $1-20(-30)$ hairs per $1 \mathrm{~cm}^{2}$, greyish felted beneath, distinctly, softly hairy to the touch. Leaflets \pm contiguous, the terminal with mid-long petiolule (petiolule $25-35 \%$ as long as its lamina), obovate to elliptical, shallowly cordate at base, \pm abruptly narrowing into a 3-6(-10) $\mathrm{mm}$ long apex; leaflet margins almost flat, indentation periodic, with incisions $2-3 \mathrm{~mm}$ deep. Petiolules on the basal leaflets 0-2 mm long. Petioles usually $5.5-8.5 \mathrm{~cm}$ long, as a rule longer than the basal leaflets, pubescent with frequent sessile to shortly stalked glands and 12-20 slender, slightly curved and distinctly declining prickles; stipules narrowly lanceolate, 1.5-2 mm wide, sparsely hairy, with scattered shortly stalked glands.

Inflorescence narrowly pyramidal panicle, with thinner, usually upwardly directed branches and peduncles, distal 3-5 cm leafless. Inflorescence leaves predominantly ternate (the uppermost 1-2 leaves simple), greyish felted beneath. Inflorescence axis \pm flexuous, densely hairy, with numerous sessile and shortly stalked glands and with $10-18$ prickles per 5 $\mathrm{cm}$ axis length; prickles slender, slightly curved, declining, 3-4 mm long. Pedicels felted, with numerous sessile and shortly stalked glands and 10-25 acicular, straight, only slightly declining, 1-1.5 mm long prickles.

Sepals 6-7 mm long, reflexed after anthesis, greyish felted, with numerous shortly stalked glands. Petals white, contiguous, somewhat undulate, hairy, ca $10 \mathrm{~mm}$ long, broadly elliptical. Stamens longer than styles, filaments white, anthers glabrous. Carpels glabrous, styles greenish. Receptacle sparsely hairy. Fruit semiglobose to globose. Flowering VI-VII (-VIII).

Illustrations: Fig. 3, Weber (1979: 11, fig. 2 (holotype)), Haeupler \& Muer (2000, 2007: 280, fig. 1512).

Chromosome number has not been reported; DNA ploidy level (stated in this study on the specimen no. R308/13 (OL) from the Czech locality mentioned below): $2 \mathrm{n}=4 \mathrm{x}$.
Taxonomy and nomenclature: Rubus fasciculatiformis is a member of series Subcanescentes H. E. Weber of the subgenus Rubus section Corylifolii Lindl. and subsection Sepincola (Focke) E. H. L. Krause. The species is somewhat variable in number of stalked glands and number of hairs on the adaxial leaf sides. From the similar $R$. fasciculatus, it can be distinguished by often only 3-4-foliolate leaves, terminal leaflet obovate in outline with periodically dentate margins and somewhat less hairy adaxial sides. Similar species $R$. scabrosus P. J. Müll. (syn.: R. visurgianus H. E. Weber) can be distinguished by leaves on firstyear stems mostly 5-foliolate, with terminal leaflet (broadly) ovate to suborbicular (its apex is usually longer, 6-10(-15) $\mathrm{mm}$ ), densely hairy above (with 20-80(-150) hairs per $\left.1 \mathrm{~cm}^{2}\right)$, first-year stem often with more hairs (also among prickles) and with small prickles, and by inflorescence often leafy to the top by simple leaves (see also Matzke-Hajek, 2004a). The first mention about the occurrence of $R$. fasciculatiformis from Bohemia came from Holub (1995). However, this is a mistake arising in the course of the upcoming volume compilation due to erroneous determination of the studied herbarium material. All mentioned information, including the description and line drawing, refers in effect to $R$. scabrosus. In the Key to the Flora of the Czech Republic (Trávníček et Havlíček, 2002: 370), this mistake was corrected, but $R$. scabrosus was shown here under the invalid name $R$. semmonicus $H$. E. Weber ined., with Czech name "o. lichosvazečkovitý". The current checklist of vascular plants of the Czech Republic (Danihelka et al., 2012) also improperly adopted the Czech name "ostružiník lichosvazečkovitý", which etymologically corresponds to the latin name $R$. fasciculatiformis. For these reasons, we propose here the Czech name "ostružiník podobný” for $R$. scabrosus.

Type material: holotype: Bayern, Lanzendorf, 24.7.1978, Reif 5935:39, herbarium M; isotype in herbarium Reif (see Weber, 1979).

Czech name (proposed here): The latin epithet of this species was chosen because of the similarity with its relative Rubus fasciculatus. Both occur in the same localities frequently (but not in Bohemia). Thus, we recommend keeping the original Czech name "ostružiník lichosvazečkovitý" for this species.

Discovered occurrence in the Czech Republic (documented by herbarium specimens): Western Bohemia, 22. Halštrovská vrchovina: Hranice village (Cheb district), approximately $1.8 \mathrm{~km}$ WNW from the church in the village, a ditch next to the road from Hranice to the hamlet of Trojmezí approximately 200 $\mathrm{m}$ E from the farm, a $\mathrm{N}$ margin of a mixture growth, 595 m a.s.1., 5638d: 50¹8’33'”N, 1209'11'”E (leg. JV, 31 August 2013, RILOG 130807); the same locality (leg. BT, 6 September 2013, R308/13, OL); the same locality (leg. JV, 5 July 2014, RILOG 140729); 


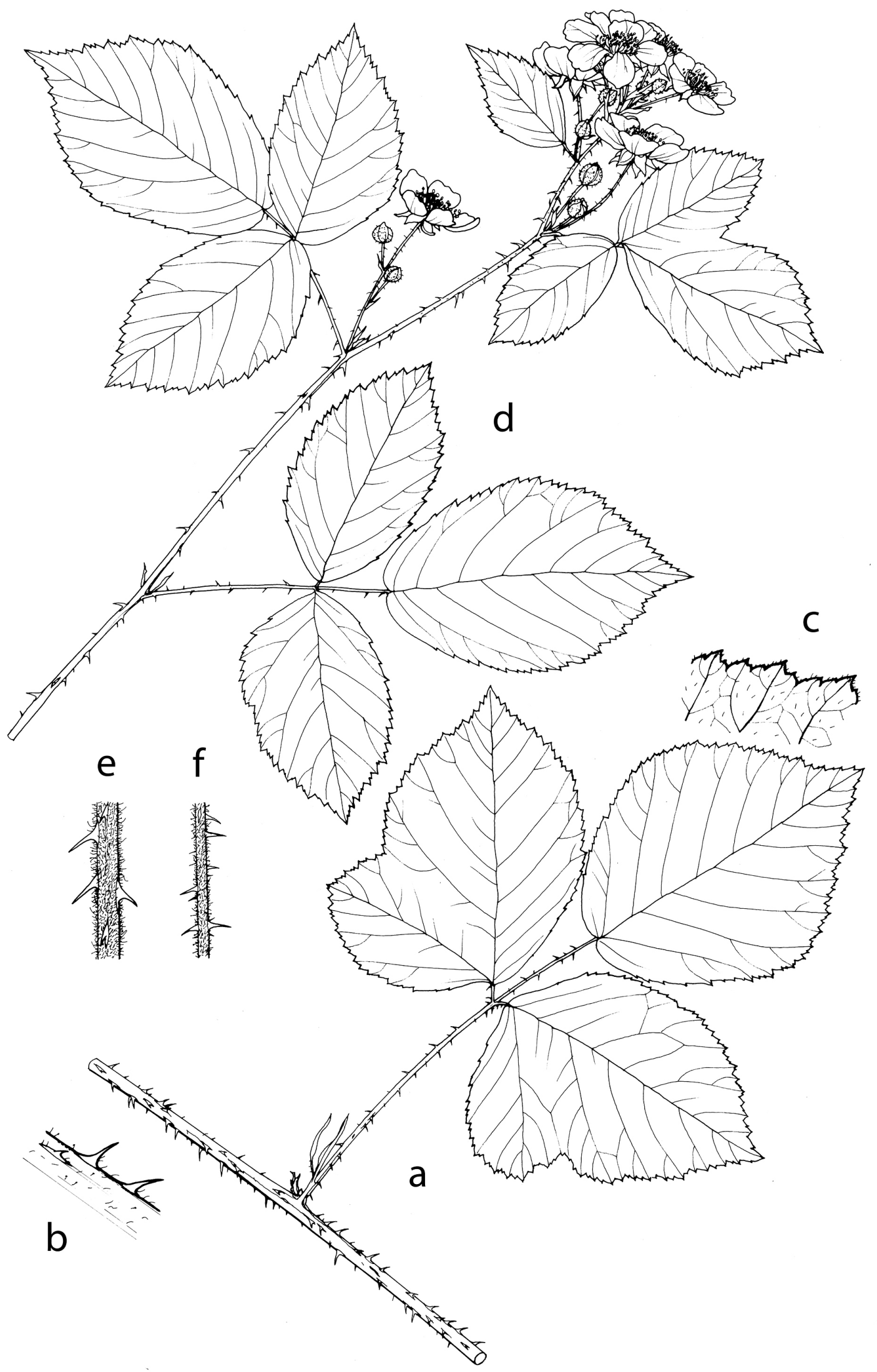

Fig. 3. Rubus fasciculatiformis: $\mathrm{a}$ - leaf with part of first-year stem; $\mathrm{b}$ - detail of first-year stem with prickles; $\mathrm{c}-$ margin of terminal leaflet showing indentations; $\mathrm{d}$ - inflorescence; $\mathrm{e}$ - detail of inflorescence axis; $\mathrm{f}$ - detail of peduncle. Drawing by A. Skoumalová 
the same locality and date (leg. $\mathrm{JH}$ and $\mathrm{VZ}$, herb. JH and VZ).

Ecology and geographical distribution: Rubus fasciculatiformis is primarily a thamnophilous species (cf. Weber, 1995b: 296). It grows in bushes or on the margins of growths and woods, usually on basic soils, but it can prosper on acidic soils (locality in the Czech Republic, above mentioned).

The species occurs in Germany and adjacent countries, specifically Belgium and Luxembourg to the west and the Czech Republic to the east. For more detailed overview, see Kurtto et al. (2010: 291, map 4646), Bettinger et al. (2013: 660).

\section{Rubus perlongus H. E. Weber \& W. Jansen, Osnabrück. Naturwiss. Mitt. 27: 82, 2001.}

Description: Shrub, usually up to $60 \mathrm{~cm}$ tall. First-year stems mainly low-arching, rooting at apex, bluntly angled with \pm convex sides, mostly 4-6 $\mathrm{mm}$ in diameter, matt greyish-green with grey bloom, at sunny sites suffused dark vinaceous, with 20-25 mainly simple hairs (1-1.5 mm long) per 1 $\mathrm{cm}$ of stem side, reaching up to prickles base; stalked glands usually 25-40 per $1 \mathrm{~cm}$ of stem side, up to 1 mm long. Prickles $12-17$ per $5 \mathrm{~cm}$ length of stem, unequal, acicular or subulate, straight to slightly curved, declining, 3-3.5 mm long, with a base 1.5-2 $\mathrm{mm}$ broad, suffused red at the base, with a yellowish tip.

Leaves on first-year stems palmate or pedate, (3-)4-5-foliolate, usually \pm flat, dark green above, covered with (0-)3-10 hairs per $1 \mathrm{~cm}^{2}$, greyish-green beneath, sparsely hairy (not distinctly to the touch), without stellate hairs. Leaflets \pm contiguous, the terminal with relatively short petiolule (petiolule $19-25 \%$ as long as its lamina), elongate ovate, rarely elliptical, shallowly cordate at base, gradually narrowing into a $25-30 \mathrm{~mm}$ long apex; leaflet margins \pm flat, indentation periodic, with incisions 2-3(-4) $\mathrm{mm}$ deep. Petiolules on the basal leaflets $0-4 \mathrm{~mm}$ long. Petioles usually 5-6 cm long, longer or faintly shorter than the basal leaflets, densely hairy, with stalked glands, acicles and 10-15 to slightly curved, declining acicular prickles; stipules filiform, ca 0.5 mm wide, sparsely hairy, with reddish stalked glands.

Inflorescence pyramidal panicle, with erecto-patent to (in upper part of inflorescence) \pm patent branches, distal 2-6 cm long part leafless. Inflorescence leaves predominantly ternate (the uppermost 1-2 leaves simple), greyish-green beneath, without stellate hairs. Inflorescence axis \pm flexuous, densely hairy, with numerous stalked glands, acicles and with $12-20$ prickles per $5 \mathrm{~cm}$ axis length; prickles slender, slightly curved, declining, 2-3 mm long. Pedicels densely pubescent, with numerous stalked glands (0.5-1 mm long, longer than hairs) and 8-18 acicular, straight, 1-2 $\mathrm{mm}$ long, prickles.

Sepals 7-10 mm long (inclusive of the conspicuous linear appendix), spreading or suberect after anthesis, later erect, greyish-green, with a white felted margin, and with numerous stalked glands and short yellowish prickles. Petals white, 7-8 mm long, ovate, not touching each other. Stamens longer than styles, filaments white, anthers glabrous. Carpels pubescent at first, later glabrous, styles with greenish base. Receptacle sparsely hairy. Fruit semiglobose to globose. Flowering VII (-VIII).

Illustrations: Fig. 4, Weber \& Jansen (2001: 83, fig. 4 (holotype), fig. 5, (stem)); Jansen \& Ranft (2003: 99).

Chromosome number has not been reported; DNA ploidy level (stated in this study on the specimen no. R300/13 (OL) from the Czech locality mentioned below): $2 \mathrm{n}=4 \mathrm{x}$.

Taxonomy and nomenclature: Rubus perlongus is a member of series Glandulosi (Wimm. et Grab.) Focke of the subgenus Rubus section Rubus and subsection Hiemales.

The significant features of this species are the long terminal leaflet with its gradually narrowing elongated tip and relatively short petiole. According to these characteristics together with the relatively sparsely hairy stems and leaves (not distinctly hairy to the touch), the species can be good distinguished from other members of series Glandulosi, which is a very difficult group of brambles. Rubus perlongus is known from at least the 1920s. It was recorded from different parts of Germany and was collected under various names (Weber \& Jansen, 2001).

Type material: holotype: Thuringia: Wald am SW-Hang des Großen Mühlberges bei Hämmern [5532.44], 27.7.1993, W. Jansen, herbarium HBG, 93727.10; isotypes: in private herbarium of W. Jansen and H. E. Weber (see Weber \& Jansen, 2001).

Czech name (proposed here): The epithet is derived from the shape of the conspicuously elongated tip of terminal leaflet lamina. Thus, we propose the name "ostružiník prodloužený".

Discovered occurrence in the Czech Republic (documented by herbarium specimens):

Western Bohemia, 22. Halštrovská vrchovina: Horní Luby village (Cheb district), approximately $350 \mathrm{~m}$ SE from the village, a margin of the golf course, an undergrowth of trees by the teeing ground of hole numbers four and five, $545 \mathrm{~m}$ a.s.l., 5740a: $50^{\circ} 15^{\prime} 45^{\prime \prime} \mathrm{N}, 12^{\circ} 23^{\prime} 48^{\prime \prime} \mathrm{E}$ (leg. JV, 10 November 2012, herb. JV 121101, the specimen was given to W. Jansen as a present); the same locality (leg. JV, 7 July 2013, RILOG 130705, two parts of sterile shoot with leaf and two fertile shoots of this collection were stored in PRC); the same locality (leg. BT, 6 Septem- 


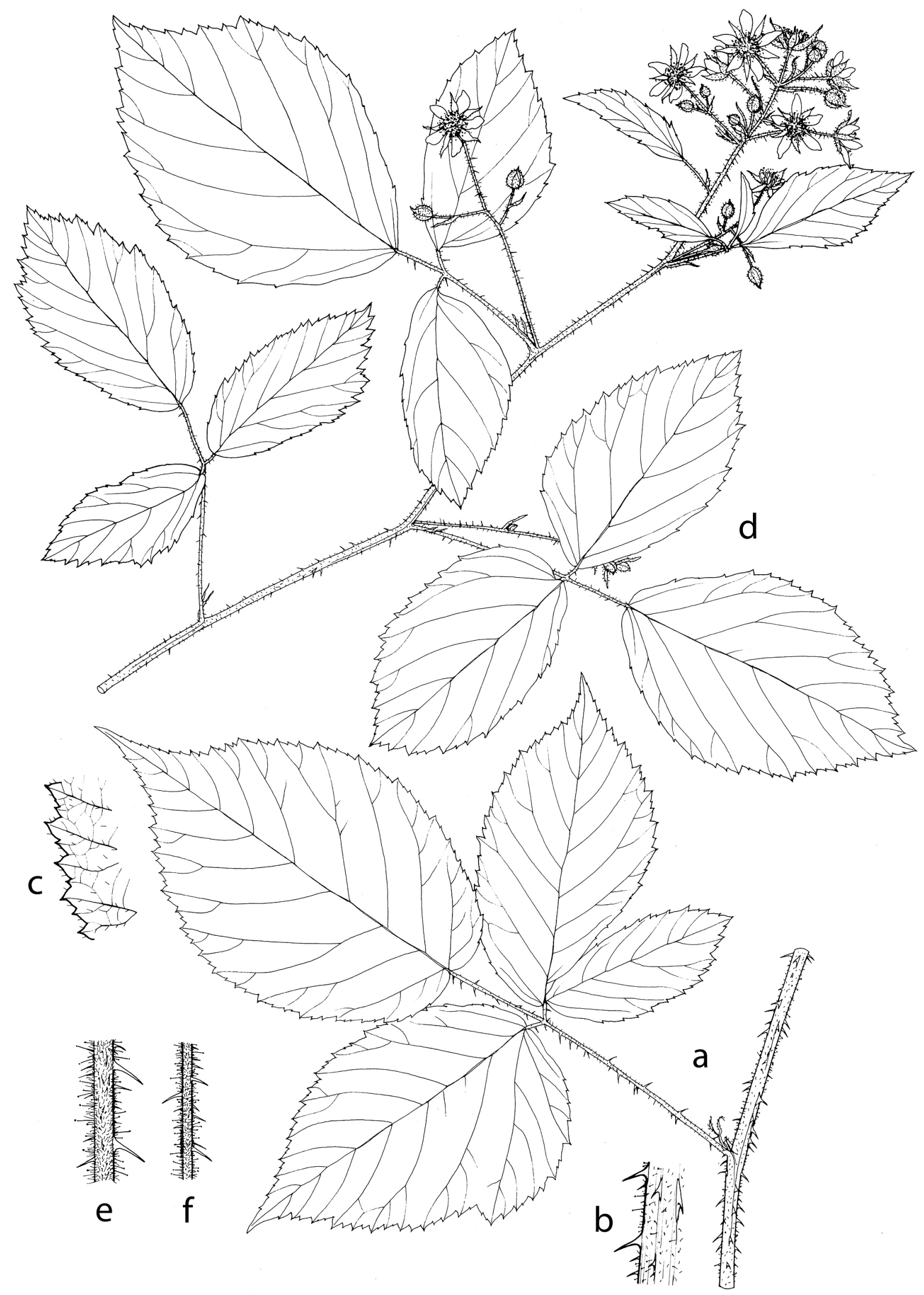

Fig. 4. Rubus perlongus: a - leaf with part of first-year stem; b - detail of first-year stem with prickles; $\mathrm{c}$ - margin of terminal leaflet showing indentations; $\mathrm{d}$ - inflorescence; e - detail of inflorescence axis; $\mathrm{f}$ - detail of peduncle. Drawing by A. Skoumalová 
ber 2013, R300/13, OL); the same locality and date (leg. JH and VZ, herb. JH and VZ); the same locality (leg. JV 5 July 2014, RILOG 140728).

Ecology and geographical distribution: It is distinctively nemophilous species, usually preferring submontane to montane localities with acidic soils. It occurs predominantly in forest habitats, as an undergrowth of woody plant groups or as a belt on margins of this biotope.

The presence of this species was known from Germany (especially from Thuringia and Bavaria), with the centre of its distribution in the Thüringer Wald mountains. For details, see Weber \& Jansen (2001: 86, fig 6), Kurtto et al. (2010: 239, map 4498) or Bettinger et al. (2013: 673). Its new-found occurrence in the western part of the Czech Republic refines its known eastern distribution border.

\section{Rubus stohrii H. E. Weber \& M. Ranft, Feddes Repert. 109 (5-6): 370, 1998.} ber

Synonymy: R. decurrentispinus auct., non H. E. We-

Description: Shrub, usually up to $80 \mathrm{~cm}$ tall. First-year stems arching, rooting at apex, angled with \pm flat sides, mostly $4-6 \mathrm{~mm}$ in diameter, matt greyish-green, often tinged with red-brown on sunlit side, glabrous, without stalked glands. Prickles nearly uniform, 5-10 per $5 \mathrm{~cm}$ length of stem, straight or slightly curved, somewhat declining, $3.5-5.5 \mathrm{~mm}$ long, with a base (3-)4-5 mm broad, greenish and/ or reddish.

Leaves on first-year stems (sub)pedate, (3-)5-foliolate, \pm flat, leaflets sometimes slightly convex, not rugose, mid to dark green above, with 5-40(-50) hairs per $1 \mathrm{~cm}^{2}$, green or indistinctly greyish beneath, with simple hairs, hairy to the touch. Leaflets contiguous, the terminal with mid-long petiolule (petiolule $24-33 \%$ as long as its lamina), broadly elliptical to ovate or suborbicular, shallowly cordate at base, subabruptly narrowing into a 10-15(-20) mm long apex; leaflet margins almost flat, indentation usually periodic, teeth rather gross, incisions $2.5-4.5 \mathrm{~mm}$ deep, sometimes with 1-2 small lobes in the middle. Basal leaflets (almost) sessile, the lateral with (0-)2-10 mm long petiolules. Petioles usually 5-7 cm long, distinctly longer than the basal leaflets, slightly pubescent, with $0-5$ stalked glands to $0.1 \mathrm{~mm}$ long and with 6-10(-13) declining and curved prickles; stipules narrowly lanceolate, $1-1.5(-2) \mathrm{mm}$ wide, sparsely hairy, sometimes with single very shortly stalked glands.

Inflorescence paniculate, indistinctly pyramidal to broadly cylindrical, truncate on the top, distal leafless part usually 3-7 cm long. Inflorescence leaves predominantly ternate (only the uppermost 1-2 often simple), leaflets with similar dentation and sim- ilarly hairy as on the first-year stems. Inflorescence axis subadpressed hairy, with simple and tufted hairs, without or rarely with individual short stalked glands and with 3-7 prickles per $5 \mathrm{~cm}$ axis length; prickles rather slender, declining, slightly curved, 2.5-4.5 mm long. Pedicels densely adpressed tufted hairy, with 0-3 stalked glands only $0.1 \mathrm{~mm}$ long and with 3-7 slightly curved, 1-2 mm long prickles.

Sepals 4-5 mm long, \pm reflexed after anthesis, greyish-green, with $0-2$ pricklets, without stalked glands. Petals pink, contiguous, undulate, finely hairy, 8-11 mm long, broad, almost roundish, often with shallow incision on the top. Stamens somewhat longer than styles, filaments whitish, anthers glabrous. Carpels glabrous, styles greenish. Receptacle only with single hairs. Fruit usually semiglobose. Flowering VI-VII(-VIII).

Illustrations: Fig. 5, Weber (1998: 371, fig. 1 (holotype), 372, fig. 2), Haeupler \& Muer (2000, 2007: 278, fig. 1495).

Chromosome number has not been reported; DNA ploidy level (stated in this study on the specimen no. R280/14 from the locality b. mentioned below): $2 \mathrm{n}=4 \mathrm{x}$. The same ploidy level was discovered in the specimen from one locality in Saxony: Sproitz village (near Nieski town), shrubs along a forest way in a clearing ca $1.2 \mathrm{~km} \mathrm{~N}$ from the village (leg. BT, 24 August 2014, R319/14, OL).

Taxonomy and nomenclature: Rubus stohrii is a member of series Subthyrsoidei (Focke) Focke of the subgenus Rubus section Corylifolii and subsection Sepincola.

Rubus stohrii was often confused with earlier described species of $R$. decurrentispinosus H. E. Weber. In Saxony, which is adjacent to northern Bohemia, only $R$. decurrentispinus was reported at first (Ranft, 1995). But Ranft (1999) states that all records about $R$. decurrentispinus from Saxony actually belong only to $R$. stohrii. Kurtto et al. (2010: 275) showed some localities of $R$. decurrentispinus also in Saxony, but after the maps in this work, $R$. stohrii is the more frequent taxon in this region. We also collected specimens in one locality of $R$. stohrii in Saxony (see above) for comparison with the Czech plants, and we can state that specimens from both regions are identical not only in morphology but also in ploidy level (i.e., tetraploid). Plants from both these regions have all the important characteristics of $R$. stohrii, including those which differ this taxon from $R$. decurrentispinus (see also Weber, 1998: 372): they have first-year stems distinctly angled (not almost round as $R$. decurentispinus) with fewer prickles, leaves on these stems are more often also with (3-)4 leaflets only, with fewer adpressed hairs, without stellate hairs beneath, teeth of leaf margin are more conspicuous, sometimes with a tendency to create 1 small lobe in the middle of the sides of the terminal leaflet, inflorescence is often 


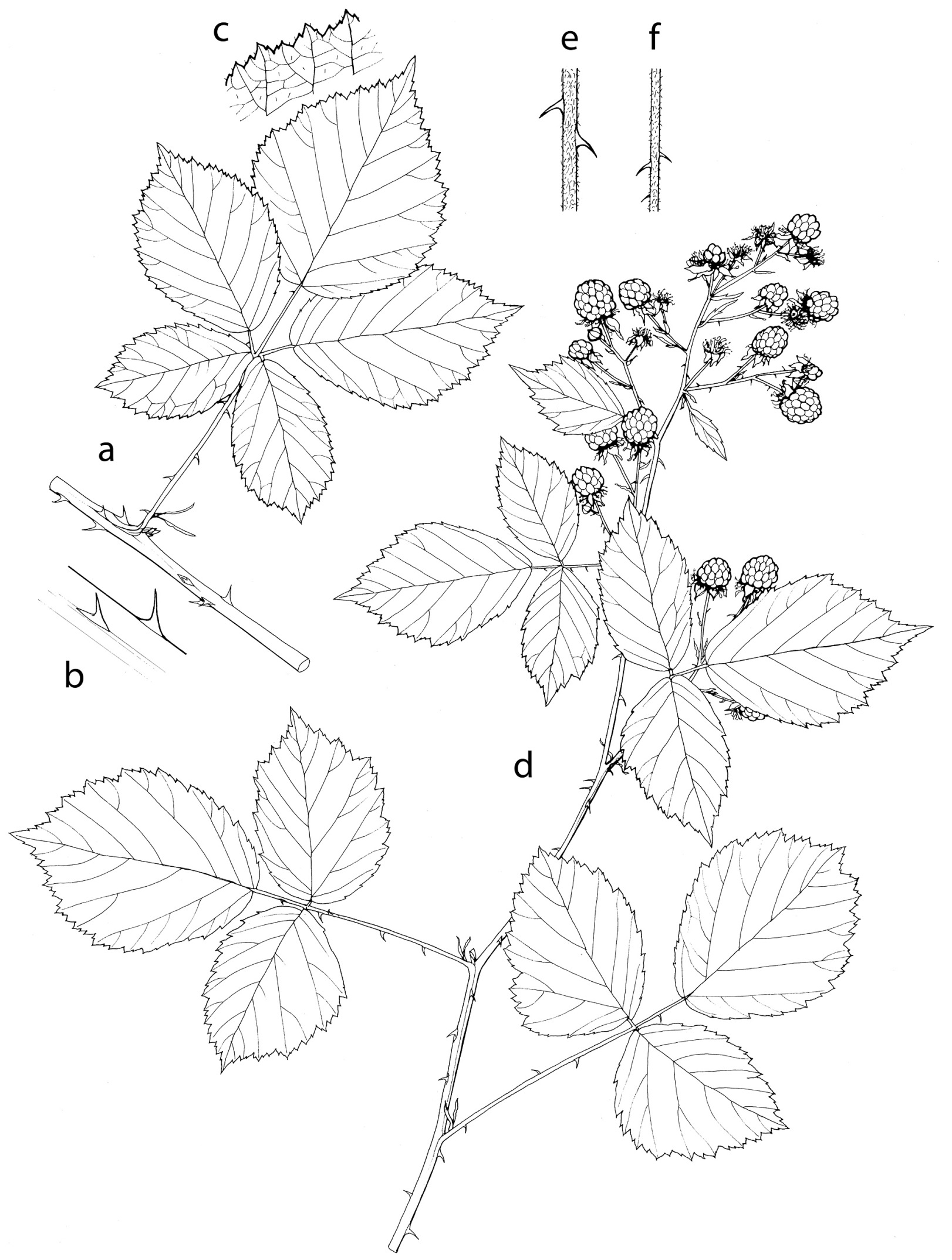

Fig. 5. Rubus stohrii: a - leaf with part of first-year stem; b - detail of first-year stem with prickles; c - margin of terminal leaflet showing indentations; $\mathrm{d}$ - infructescence; $\mathrm{e}$ - detail of inflorescence axis; $\mathrm{f}$ - detail of peduncle. Drawing by A. Skoumalová 
more voluminous, petals are somewhat smaller (not 11-14 mm long as in $R$. decurrentispinus) and always distinctly pink. In the Czech Republic, no specimens morphologically corresponding to $R$. decurrentispinus are known. Plants similar to both discussed species are rarely found, but all these specimens are different from these taxa based on more characteristics.

Type material: holotype: Germania, Sachsen Anhalt, südlich Lubast, Einfahrt von der B2 zur Kiesgrube (4241.31), 26.7.1996, Weber 96.726.4, herbarium B; isotypes in herbarium We.

Czech name (proposed here): "ostružiník Stohrův".

Discovered occurrence in the Czech Republic (documented by herbarium specimens): (a.) Northern Bohemia, 53a. Českolipská kotlina: Stružnice village (Česká Lípa district), shrubs along the way near railway at the northern village margin, ca $0.2 \mathrm{~km}$ $\mathrm{E}$ of the railway station, ca $250 \mathrm{~m}$ a.s.l., 5352b:

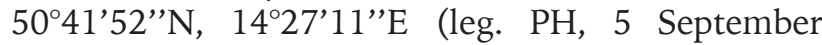
2001, herb. PH); the same locality (leg. BT, 22 August 2014, R278/14, OL); the same locality and date (leg. RH, HOMP); (b.) Northern Bohemia, 53a. Českolipská kotlina: Zahrádky village (Česká Lípa district), shrubs along the road towards Sosnová village, ca $0.8 \mathrm{~km}$ NNE of the centre of Zahrádky, ca $290 \mathrm{~m}$ a.s.l., 5353c: 50³8'22” N, 14³1'46” E (leg. PH, 1 September 2000, herb. PH); the same locality (leg. BT, 22 August 2014, R280/14, OL).

Ecology and geographical distribution: Rubus stohrii grows usually in bushes along roads and ways (both Czech localities have this characteristic) or at railways, in quarries, on margins of woods (cf. Ranft, 1999); thus, it is a thamnophilous bramble species (cf. Weber, 1995b: 296). The soils of the sites of the species are usually moderately dry to fresh, sandy to loamy, weakly acidic.

The species has a large area of general distribution (it is a widespread bramble species - see Weber, 1999), it covers the country of Germany (Brandenburg, Berlin, Saxony-Anhalt, Thuringia, Saxony and Bayern), see Weber (1998: 373), Kurtto et al. (2010: 279) and Bettinger et al. (2013: 680). The newly discovered localities in the Czech Republic are a continuation of the species occurrence in Saxony. Therefore, there is a high possibility of finding some others localities in northern Bohemia, especially in the wider vicinity of the town of Česká Lípa, where sites of $R$. stohrii are already known. Finding the species in adjacent parts of western Poland is also highly probable.

\section{Acknowledgements}

We are grateful to H. E. Weber (Bramsche, Germany) for the revision of the determination of Rubus adornatus, $R$. fasciculatiformis and R. stohrii, W. Jansen (Itzehoe, Germany) for the revision of the determination of $R$. adornatus and $R$. perlongus. The finding of species was performed in fieldwork cooperation with follow colleagues: V. Žíla (Strakonice), J. Hadinec (Praha) and R. Hlaváček (Příbram). For revising the English of the manuscript we are grateful to the American Journal Experts team. This study was supported by internal grants of the Silva Tarouca Research Institute for Landscape and Ornamental Gardening (VUKOZ-IP-00027073), of Palacký University (IGA_PrF_2014-001, IGA_PrF_2015_001) and grant No. LO1204 (Sustainable developmént of

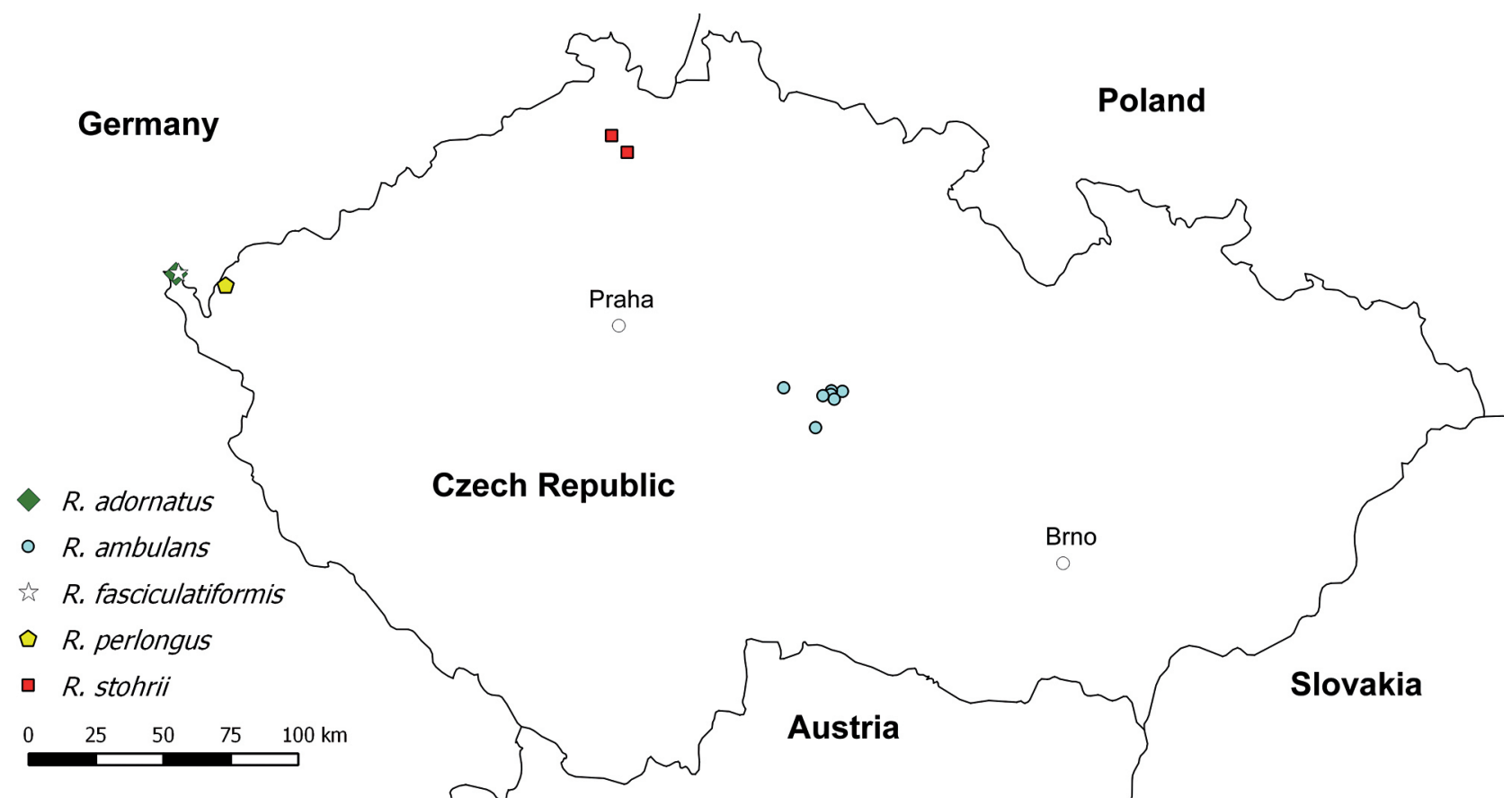

Fig. 6. Localities of new bramble species in Czech Republic 
research in the Centre of the Region Haná) from the National Program of Sustainability I, MEYS.

\section{References}

Bettinger A., Buttler K. P., Caspari S., Klotz J., May R. \& Metzing D. (red.) 2013. Verbreitungsatlas der Farn- und Blütenpflanzen Deutschlands. Netzwerk Phytodiversität Deutschland \& Bundesamt für Naturschutz (Hrsg.), Landwirtschaftsverlag, Münster.

Brummitt R. K. \& Powell C. E. (eds.) 1992. Authors of plant names. Royal Botanic Gardens, Kew.

Danihelka J., Chrtek J. Jr. \& Kaplan Z. 2012. Checklist of vascular plants of the Czech Republic. Preslia 84: 647-811.

Doležel J., Binarová P. \& Lucretti S. 1989. Analysis of nuclear DNA content in plant cells by flow cytometry. Biologia Plantarum 31: 113-120.

Doležel J., Greilhuber J. \& Suda J. 2007. Estimation of nuclear DNA content in plants using flow cytometry. Nature Protocols 2: 2233-2244.

Ehrendorfer F. \& Hamann U. 1965. Vorschlage zu einer floristischen Kartierung von Mitteleuropa. Berichte der Deutschen Botanischen Gesellschaft 78: 35-50.

Haeupler H. \& Muer T. (eds.) 2000. Bildatlas der Farn- und Blütenpflanzen Deutschlands. Verlag Eugen Ulmer, Stutgart.

Haeupler H. \& Muer T. (eds.) 2007. Bildatlas der Farn- und Blütenpflanzen Deutschlands, ed. 2. Verlag Eugen Ulmer, Stutgart.

Helminger T. 2009. Checklist of the brambles (Rubus L. subgenus Rubus, Rosaceae) of Luxembourg. Bulletin de la Société des naturalistes luxembourgeois 110: 53-67.

Holmgren P. K., Holmgren N. H. \& Barnett L. C. 1990. Index herbariorum. Part I: Herbaria of the World. Ed. 8. Regnum Vegetabile 120: 1-693.

Holub J. 1995. Rubus L. - ostružiník (maliník, moruška, ostružinec, ostružiníček). In: Slavík B. (ed.), Květena České republiky, Vol. 4, Academia, Praha, pp. 54-206.

The New York Botanical Garden, Index Herbariorum: A Global Directory of Public Herbaria and Associated Staff (Index Herbariorum). [HOMP, Okresní muzeum Př́bram Březové Hory]. http://sweetgum.nybg.org/ih/herbarium.php?irn $=125601$ (accesed 29 September 2015).

The International Plant Names Index (IPNI). [Rubus ambulans, $R$. perlongus, $R$. stohrii]. http://www. ipni.org/ (accessed 6 May 2015).

Jansen W. \& Ranft M. 2003. Die Gattung Rubus L. in Sachsen - 2. Nachtrag. Sächsische Floristische Mitteilungen 8: 96-108.
Kurtto A., Weber H. E., Lampinen R. \& Sennikov A. N. (eds.) 2010. Atlas Florae Europaeae. Distribution of Vascular Plants in Europe. 15. Rosaceae (Rubus). The Committee for Mapping the Flora of Europe \& Societas Biologica Fennica Vanamo, Helsinki.

Lepší M. \& Lepší P. 2006. Rubus kletensis, a new species from South Bohemia and Upper Austria. Preslia 78: 103-114.

Lepší M. \& Lepší P. 2009. Rubus silvae-norticae, a new species from Bohemia, Austria and Bavaria and the significance of brambles for regional migrations. Preslia 81: 43-62.

Matzke-Hajek G. 1993. Die Brombeeren (Rubus fruticosus-Agg.) der Eifel und der Niederrheinischen Bucht. Decheniana-Beihefte (Bonn) 32: 1-212.

Matzke-Hajek G. 2004a. Bestimmungshilfe für die Haselblatt-Brombeeren der Serie Subcanescentes H. E. Weber (Rubus L., Rosaceae) in Berichte der Botanichen Arbeitsgemeinschaft Südwestdeutschland 3: 19-32.

Matzke-Hajek G. 2004b. Was ist Rubus gremlii? Berichte der Bayerischen Botanischen Gesellschaft 73/74: 17-34.

Ranft M. 1995. Die Gattung Rubus L. in Sachsen. Abhandlungen und Berichte des Naturkundemuseums Görlitz 68/6 : 1-97.

Ranft M. 1999. Die Gattung Rubus L. In Sachsen 1. Nachtrag. Sächsische Floristische Mitteilungen 5: 94-96.

Skalický V. 1988. Regionálně fytogeografické členění. In: Hejný S. \& Slavík B. (eds.), Květena České socialistické republiky, Vol. 1, Academia, Praha, pp. 103-121.

Sudre H. 1912. Rubi Europae vel Monographia Iconibus Illustrata Ruborum Europae. Paris.

Trávníček B. \& Havlíček P. 2002. Rubus L. - ostružiník. In: Kubát K., Hrouda L., Chrtek J. jun., Kaplan Z., Kirschner J. \& Štěpánek J. [eds.], Klíč ke květeně České republiky, Academia, Praha, pp. 329-376.

Trávníček B. \& Zázvorka J. 2005. Taxonomy of Rubus ser. Discolores in the Czech Republic and adjacent regions. Preslia 77: 1-88.

Weber H. E. 1979. Beitrag zur Kenntnis der Rubi sect. Corylifolii (Focke) Frid. in Bayern und angrenzenden Gebieten. Berichte der Bayerischen Botanischen Gesellschaft 50: 5-22.

Weber H. E. 1995a. Zu den Typen der Brombeeren (Rubus L. subgen. Rubus) im Musée botanique cantonal vaudois (LAU). Candollea 50: 33-39.

Weber H. E. 1995b. Rubus L. In: Weber H. E. (ed.) Gustav Hegi's Illustrierte Flora von Mitteleuropa. 3nd ed., vol. 4/2a. Blackwell Wissenschafts-Verlag, Berlin und Oxford, pp. 284-595.

Weber H. E. 1998. Zwei neue Rubus-Arten aus Mittel- und Ostdeutschland. Feddes Repertorium 109: 369-377. 
Weber H. E. 1999. Present state of taxonomy and mapping of blackberries (Rubus L.) in Europe. Acta Botanica Fennica 162: 161-168.
Weber H. E. \& Jansen W. 2001. Zwei neue Brombeerarten der Serie Glandulosi (Wimmer \& Grabowski) Focke aus Mitteleuropa. Osnabrücker Naturwissenschaftliche Mitteilungen 27: 77-87. 